\title{
Analisis Pola Hubungan Kerja Antar Tenaga Medis dalam Melayani Pasien Diabetes dan Komplikasinya pada Rawat Inap RS XYZ Menggunakan Teknik Process mining
}

\author{
Muhammad Rafdi Syarifuddin dan Mahendrawathi ER \\ Jurusan Sistem Informasi, Fakultas Teknologi Informasi, Institut Teknologi Sepuluh Nopember (ITS) \\ Jl. Arief Rahman Hakim, Surabaya 60111 Indonesia \\ e-mail:mahendrawati.er@gmail.com, rafdi.s12@mhs.is.its.ac.id
}

\begin{abstract}
Abstrak-Rumah Sakit (RS) XYZ merupakan salah satu rumah sakit yang telah menerapkan sistem informasi rumah sakit untuk merekam segala proses penanganan dan perawatan pasien. Salah satu penyakit yang ditangani oleh rumah sakit ini yaitu penyakit diabetes yang mana memiliki resiko kematian yang cukup tinggi. Tentunya sebagai rumah sakit, nyawa dan kesehatan pasien adalah prioritas utama. Namun pada pelaksanaannya tidak jarang ditemui bahwa proses perawatan tiap pasien memakan waktu yang tidak sedikit. Hal ini dapat disebabkan oleh, salah satunya, keterlibatan antar individu pelaku dalam proses perawatan. Untuk itu diperlukan pemodelan terhadap proses bisnis (alur kerja para aktor yang terlibat) untuk mengetahui pola dan hubungan pekerjaan di antara mereka. Dalam Tugas Akhir ini, pemodelan proses bisnis pada bagian rawat inap penyakit diabetes dilakukan dengan menggunakan process mining. Teknik process mining dipilih karena dengan menggunakan metode ini dapat diketahui pola alur dan tingkah laku para aktor dalam bekerja dari pemodelan alur yang memanfaatkan event log yang sudah didapatkan dari sistem informasi RS XYZ. Kemudian event log tersebut digunakan membentuk social network menggunakan algoritma social network miner. Dari hasil pemodelan dilakukan analisis alur pelayanan pasien dan alur pekerjaan oleh para aktor. Selanjutnya dilakukan analisis kontribusi aktor secara individu mengenai siapa yang paling sering dan paling jarang berkontribusi sehingga nantinya akan diperoleh informasi atau pengetahuan mengenai siapa atau bagian mana yang sekiranya perlu diberi peningkatan, seperti apa alur pelayanan yang paling umum bagi pasien serta siapa yang berkontribusi paling besar agar proses perawatan menjadi lebih efektif, efisien, dan diharapkan lebih singkat.
\end{abstract}

Kata Kunci-Alur Pekerjaan, Event log, Penyakit Dalam, Rumah Sakit, Social network Analysis

\section{PENDAHULUAN}

$\mathrm{S}$ AAT ini teknologi telah membuat beberapa perubahan dalam kehidupan manusia dan juga dalam organisasi serta perusahaan. Bukan hal yang baru lagi jika rumah sakit -baik dalam tingkat lokal/domestik, atau tingkat global/internasionalsedang mencoba untuk meningkatkan efektifitas dan efisiensi pada prosedur perawatan dan layanan pasien mereka supaya tetap mampu beroperasi dengan baik selayaknya rumah sakit lain pada umumnya. Di sisi lain, tahun demi tahun, jumlah pasien yang merujuk ke rumah sakit semakin bertambah [1].

Salah satu teknologi yang saat ini dikembangkan dan dipakai oleh banyak rumah sakit adalah sistem informasi rumah sakit. Sistem informasi ini utamanya digunakan untuk mencatat aktifitas pasien yang berkunjung dan berobat ke rumah sakit. Salah satu manfaat dari sistem informasi tersebut bagi rumah sakit yaitu untuk mengintegrasikan data-data pasien dari semua bagian di rumah sakit tersebut. Selain itu, sistem informasi juga dapat bermanfaat pula dalam memudahkan pelayanan dan mengelola rekam jejak data pasien, sebagai salah satu layanan informasi penting bagi rumah sakit.

Pada beberapa rumah sakit, khususnya di negara-negara berkembang, pasien banyak yang menunggu yang merupakan bagian dari proses perawatan mereka. Hal ini salah satunya disebabkan oleh proses perawatan per pasien yang durasinya cukup lama terutama jika pasien tersebut perlu melakukan uji lab. Sementara itu, jumlah pasien yang melakukan uji lab pada setiap kunjungannya tidak sedikit. Pada akhirnya, mengurangi jumlah waktu tunggu pada rumah sakit (antara bagian yang berbeda) menjadi penting baik bagi pasien dan bagi manajemen rumah sakit karena selain dapat mengurangi biaya dan pengeluaran juga dapat meningkatkan kepuasan pasien. Salah satu aksi yang dibutuhkan untuk mengurangi waktu tunggu untuk perawatan pasien adalah untuk mengatur personil pada rumah sakit dengan menggunakan bantuan sistem informasi rumah sakit [2].

Masalah di atas dialami oleh bagian/poli yang memerlukan proses perawatan khusus, salah satunya yaitu bagian rawat inap penyakit dalam, khususnya diabetes, merupakan salah satu bagian di rumah sakit yang cukup sibuk. Mengingat bahwa hampir semua pasien diabetes memerlukan proses perawatan yang kompleks, maka cukup sering terjadi antrian yang tidak sebentar untuk sektor ini. Ditambah lagi jika adanya pembagian pekerjaan antar tenaga medis yang tidak merata, dapat menyebabkan bertambahnya waktu tunggu bagi pasien.

Untuk mengatasi hal tersebut, salah satu hal yang bisa dilakukan yaitu dengan menganalisa hubungan dan pola pekerjaan antar aktor (dokter, suster/perawat, laboran). Analisa hubungan kerja ini bertujuan supaya pihak rumah sakit dapat mengelompokkan para aktor dalam suatu diagram atau model dan supaya mengetahui pola hubungan dan pekerjaan di antara 
mereka. Untuk melakukannya, perlu dilakukan ekstraksi data dari sistem informasi rumah sakit untuk mendapatkan data yang dibutuhkan. Salah satu teknik untuk melakukan ekstraksi data dan mengevaluasi sebuah proses bisnis adalah teknik penggalian proses, dengan algoritma jaringan sosial (social network).

Teknik penggalian proses adalah sebuah disiplin ilmu yang menggabungkan antara machine learning dan penggalian data pada satu sisi serta pemodelan proses dan analisis pada sisi lainnya. Tujuan dari teknik penggalian proses adalah untuk menemukan, memantau, dan memperbaiki proses sebenarnya dengan cara melakukan ekstraksi pengetahuan dari catatan kejadian yang tersedia [3]. Catatan kejadian merupakan rekaman data yang berisi tentang kejadian-kejadian yang terjadi dalam sebuah perusahaan, waktu pelaksanaan, orang atau sistem yang melaksanakan tugas. Salah satu cara untuk mendapatkan catatan kejadian adalah dengan cara mengekstrak basis data sistem informasi yang ada [4].

Social network Analysis atau biasa disingkat SNA, merupakan sebuah algoritma dalam penggalian proses (process mining) yang didukung oleh "ProM", terdiri atas 3 pengukuran (metric) utama yaitu: working together metric, handover of work metric, dan similar tasks metric. Disebut juga sebagai Social Network Miner [4], fungsinya yaitu menganalisis jaringan sosial (social network) dari event log seperti mencari pola kolaborasi kerja tiap aktor dalam mengerjakan suatu tugas oleh orang-orang dalam suatu organisasi serta mengevaluasi hubungan antar orang, tim, maupun seluruh organisasi [5]. Analisis ini dapat menyajikan informasi penting untuk meningkatkan alur komunikasi dalam organisasi dan membuat manajer dapat mengetahui bagaimana suatu pekerjaan diselesaikan secara informal. Tujuan utama dari SNA adalah untuk membuat proses komunikasi menjadi transparan dan menyediakan alat untuk membuat semua proses komunikasi menjadi lebih baik dan lancar.

Dalam penelitian ini akan dilakukan penggalian dan analisis terhadap log aktifitas dokter maupun aktor lain untuk mengetahui hubungan dan pola pekerjaan di antara mereka. Dengan mengetahui hubungan tersebut, diharapkan akan ditemukan suatu pola kerjasama (working together) maupun peralihan pekerjaan (handover of work) antar actor terhadap penanganan pasien. Analisis akan dilakukan menggunakan teknik jejaring sosial (social network) menggunakan event log yang diambil dari sistem informasi RS XYZ bulan Desember 2015 hingga Mei 2016. Dengan mengetahui kelompok hubungan tersebut, diharapkan hasil analisis nantinya dapat membantu para aktor rumah sakit (dokter, laboran, serta termasuk administratornya) untuk mengetahui alur transaksi maupun perawatan yang tepat antar aktor serta supaya dapat meningkatkan proses perawatan secara efektif, efisien, dan tepat waktu. Penelitian ini juga dapat digunakan untuk mencari tahu siapa yang memiliki kontribusi terbesar selama proses perawatan dan siapa yang memiliki peran sedikit supaya nanti hasilnya dapat digunakan oleh pihak rumah sakit untuk mempertimbangkan dalam menyusun ulang baik jadwal para aktor maupun pembentukan tim di antara mereka.

\section{II.METODOLOGI PENELITIAN}

Penelitian ini dilakukan melalui beberapa metode Gambar 1 menjelaskan urutan dari metodelogi penelitian. Terdapat sebanyak 11 metode yang dilakukan dalam penelitian ini, dimulai dari identifikasi masalah hinga penyusunan (buku) tugas akhir.

Tahapan awal penelitian yaitu identifikasi masalah dilakukan dengan tujuan untuk mempersiapkan dan mempelajari masalah yang ada supaya dapat didapat topik yang akan diambil. Setelah topik dan masalah didapat, dilakukan studi literatur. Studi literatur dilakukan dengan mengumpulkan referensi baik dari narasumber langsung, dari buku atau penelitian sebelumnya. Tujuannya adalah untuk lebih memahami dasardasar teori yang berhubungan dengan permasalahan. Studi literatur dapat membantu peneliti dalam mencari sumber yang dapat dipercaya dan latar belakang permasalahan yang diangkat dalam penelitian ini. Setelah diketahui teori-teori dasar dalam melakukan penelitian, maka sebelum memulai pengumpulan data, dilakukan penentuan atribut data karena harus mengetahui terlebih dahulu data yang seperti apa yang akan diambil dari sistem informasi rumah sakit. Di mana data yang dibutuhkan adalah data yang memiliki case ID, event, aktivitas, originator dan timestamp. Setelah mengetahui dasar-dasar penelitian, maka dilakukan ekstraksi data untuk proses selanjutnya. Data diambil dari sistem informasi manajemen rumah sakit bagian billing melalui Departemen IT. Dari proses pengumpulan data ini didapatkan data mentah yaitu berupa id kunjungan, tanggal kunjungan, id pasien, tanggal lahir pasien, jenis kelamin pasien, id dokter, keterangan ditambah dengan data mengenai perlakuan medis pasien. Pengumpulan data ini yang nantinya akan dilakukan proses selanjutnya, yaitu menstrukturkannya.

Strukturisasi data merupakan proses pengolahan data mentah menjadi event log. Event $\log$ yang terbentuk yaitu ID berupa ID Pasien, event berupa perlakuan aktor, aktivitas berupa penyakit, timestamp berupa tanggal dan jam kunjungan dan originator berupa aktor. Strukturisasi data akan dilakukan menggunakan Microsoft Excel dan software disco. Event log ini nantinya yang akan dibutuhkan untuk membuat model yang akan dianalisis. Setelah mendapatkan event log, maka dari data tersebut dapat dibuat pemodelan proses bisnisnya melalui Process mining. Pembuatan model ini dilakukan dengan software ProM 6.5.1. menggunakan algoritma Social network Miner. Keluaran dari proses ini adalah grafik/model Social network. Model ini kemudian akan dilakukan evaluasi. Evaluasi dilakukan terhadap model Petri net dan social network yang terbentuk hingga dihasilkan model yang valid. Dari hasil kedua proses tersebut, dilakukan analisis pada social network antar aktor yang didapat dari event log yang direkam oleh Sistem Informasi Rumah Sakit. Analisis dilakukan untuk mengetahui bagaimana kinerja dan hubungan setiap aktor yang ada di rawat inap penyakit dalam RSI Jemursari serta hubungan dokter terhadap lab yang ada. Analisis kinerja aktor ini dilihat dari seberapa sering aktor berinteraksi dengan aktor lain. Langkah terakhir adalah menyimpulkan dari hasil analisis model yang didapat dari proses sebelumnya, sehingga dapat ditarik kesimpulan yang dapat menjawab pokok permasalahan dari penelitian ini. Setelah seluruh proses dalam penelitian mengenai 
analisa kinerja mahasiswa untuk tiap angkatan dilihat dari pola pengambilan mata kuliah, selanjutnya melakukan penyusunan laporan tugas akhir.

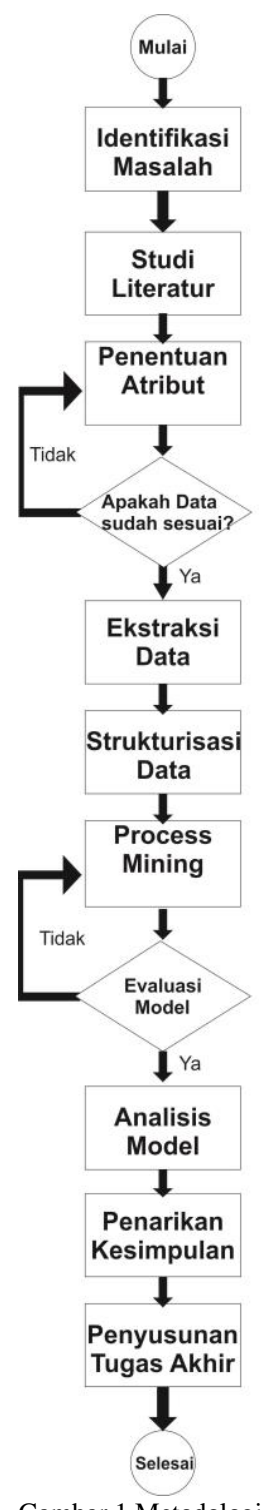

Gambar 1 Metodologi Penelitian

\section{HASIL DAN PEMBAHASAN}

\section{A. Analisis Alur Perawatan Pasien}

Analisis yang pertama adalah analisis alur perawatan pasien. Analisis ini dilakukan dengan menggunakan ProM 6.5.1 untuk menghasilkan model Petri net menggunakan inductive miner. Dengan melihat Petri net, dapat diketahui seperti apa alur perawatan pasien yang terjadi menurut event log yang ada, mulai dari awal (start) hingga selesai (finish). Alur perawatan pasien di sini lebih fokus kepada alur perawatan pada bagian/pihak tertentu yang menangani pasien, bukan jenis aktifitas yang diterima pasien. Untuk itu, juga diperlukan model social network yang dihasilkan melalui ProM 5.2 untuk mengetahui alur penyerahan pekerjaan secara umum yang menggambarkan alur perawatan pasien.
Melalui Petri net, dapat diketahui bahwa semua proses perawatan diawali dengan aktifitas "Administrasi UGD" seperti yang ditunjukkan pada gambar 2 .

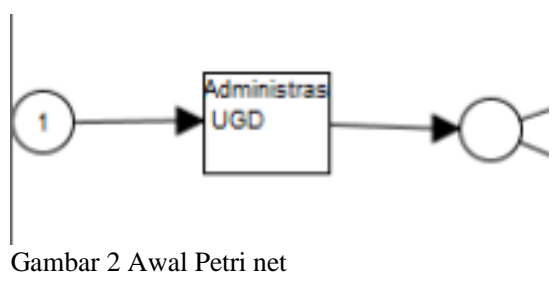

Sedangkan untuk akhir dari proses perawatan, diketahui bahwa aktifitas "Administrasi" merupakan aktifitas yang terdapat di akhir Petri net seperti yang ditunjukkan gambar 3 .

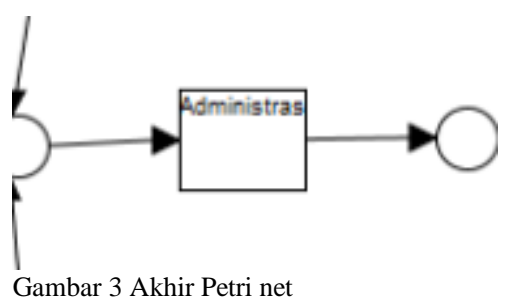

Dari kedua pengamatan di atas didapat informasi bahwa semua proses perawatan pasien diabetes rawat inap selalu diawali dengan "Administrasi UGD" dan diakhiri dengan "Administrasi". Nantinya melalui nama aktifitas ini dapat diketahui pihak/bagian mana yang melakukan aktifitas ini. Sedangkan untuk aktifitas-aktifitas yang berada di tengahtengah keduanya tidak dapat dilihat pada Petri net karena terlalu kompleks (melebar), sehingga susah untuk menentukan aktifitas maupun pihak mana yang bekerja berurutan. Oleh karena itu analisis dilanjutkan dengan menggunakan diagram social network.

Melalui social network dapat diketahui bagian/pihak mana yang melakukan aktifitas di tengah-tengah antara awal maupun akhir. Sebelumnya, dilakukan generalisasi dari semua nama tenaga medis sesuai dengan bagian/pekerjaan mereka pada rumah sakit (dilihat dari event log). Berikut adalah generalisasi yang dilakukan:

- Semua tenaga medis yang berakhiran “-,dr." digolongkan sebagai "Dokter". Dokter di sini melakukan aktifitas sebagai penerima pasien (administrasi UGD) dan melakukan tes medis awal seperti EKG/ECG, GDA/GDR.

- Semua tenaga medis yang berakhiran "-,SP.-“ digolongkan sebagai "Dokter Spesialis", kecuali SP.PK dan SP.Rad karena aktifitas yang dilakukannya berbeda dari dokter spesialis, yang mana mayoritas hanya berupa "Visite Dokter Spesialis".

- Tenaga medis dengan akhiran SP.PK diubah menjadi "Lab PK" karena bertugas pada Lab Patologi Klinik. Pihak Lab PK melakukan segala aktiftias yang berhubungan dengan uji ataupun pengecekan kondisi pasien. Misalnya, uji darah, ureum.

- Tenaga medis dengan akhiran SP.Rad diubah menjadi "Radiolog" karena bertugas pada Lab Radiologi. Tugas pihak 
Radiolog mayoritas berupa "Scan" pasien, baik itu terhadap kepala, thorax dan lain-lain.

- Tenaga medis "Perawat" tidak diubah karena sejak awal sudah tergeneralisasi. Perawat melakukan aktifitas yang bertujuan untuk merawat pasien sehari-hari seperti suntik, memasang infus.

Setelah semua tenaga medis event log sudah digeneralisasi seperti ketentuan di atas, maka dibuat diagram social networknya melalui ProM 5.2. Event $\log$ yang digunakan terdiri atas 51 case, 5 aktor/resource dan 119 jenis aktifitas. Analisis dilakukan menggunakan handover of work metric dengan mempertimbangkan causality. Untuk hasil perhitungan terhadap bobot penyerahan pekerjaan tiap aktor menggunakan causality dapat dilihat pada Tabel 1 .

Tabel 1

Hasil perhitungan social network

\begin{tabular}{c|lcccc}
\hline \hline & Dokter & $\begin{array}{c}\text { Dokter } \\
\text { Spesialis }\end{array}$ & Lab PK & Perawat & Radiologi \\
\hline Dokter & $0,0987654 \ldots$ & 0,0 & $0,0267489 \ldots$ & $0,0061728 \ldots$ & $0,0113168 \ldots$ \\
Dokter & 0,0 & $0,0030864 \ldots$ & $0,0154320 \ldots$ & $0,0308641 \ldots$ & $0,0051440 \ldots$ \\
Spesialis & & $0,0123456 \ldots$ & $0,3899176 \ldots$ & $0,0925925 \ldots$ & $0,0164609 \ldots$ \\
Lab PK & $0,0082304 \ldots$ & $0,0205761 \ldots$ & $0,0390946 \ldots$ & $0,1851851 \ldots$ & $0,0010288 \ldots$ \\
Perawat & 0,0 & $0,0010288 \ldots$ & $0,0133744 \ldots$ & $0,0154320 \ldots$ & $0,0051440 \ldots$ \\
Radiologi & $0,020576 \ldots$ & &
\end{tabular}

Untuk melakukan analisa secara lebih fokus dan mendalam, serta untuk mengetahui secara lebih jelas alur perawatan pasien, maka nilai threshold pada social network dinaikkan menjadi 0,0167. Diagram social network yang terbentuk ditunjukkan pada gambar 4 .

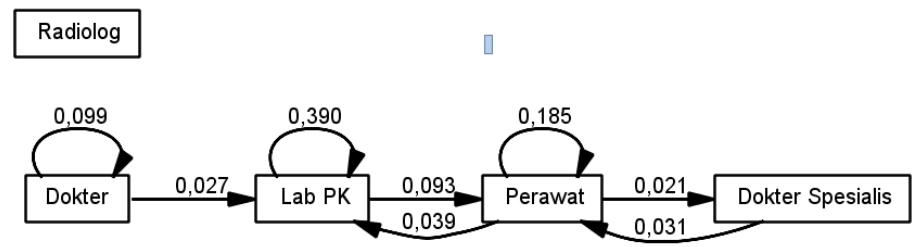

Gambar 4 Social network yang tergeneralisasi $(\mathrm{t}=0,0167)$

Gambar di atas dianggap sudah cukup menggambarkan seperti apa alur perawatan pasien dilihat dari pola penyerahan pekerjaan antar pihak/bagian.

Dari Petri net diketahui bahwa semua proses perawatan pasien dimulai dengan "Administrasi UGD" dan diakhiri dengan "Administrasi". Melalui event log diketahui bahwa
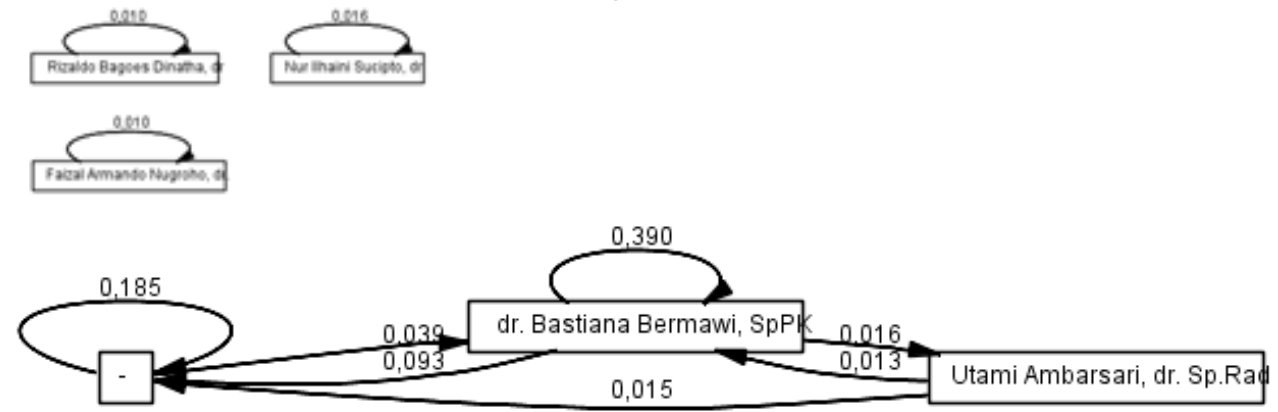

Gambar 5 Diagram social network dengan causality aktifitas "Administrasi UGD" dikerjakan oleh pihak "Dokter" dan aktifitas "Administrasi" dikerjakan oleh pihak "perawat".

Melalui segala informasi di atas, berikut adalah hasil analisis dari hasil perhitungan dan pola pada diagram yang dihasilkan mengenai alur pelayanan pasien:

- Dokter (umum) merupakan aktor yang memulai semua aktifitas, dilihat dari tidak adanya pekerjaan yang diserahkan kepada dokter. Hal ini dapat dikarenakan semua pasien rawat inap masuk melalui bagian UGD.

- Aktor Radiolog terisolasi, dapat berarti bahwa peran Radiolog tidak terlalu banyak pada proses perawatan pasien.

- Dengan informasi bahwa semua proses perawatan pasien selalui diawali oleh Dokter dan diakhiri oleh Perawat, serta melalui diagram social network di atas, terdapat beberapa mayoritas alur perawatan pasien yang memungkinkan, yaitu melalui:

- Dokter - Lab PK - Perawat - Dokter spesialis - Perawat

- Dokter - Lab PK - Perawat

o Dokter - Lab PK - Perawat - Dokter spesialis - Perawat

- Dokter - Lab PK - Perawat - Lab PK - Perawat

o okter - Lab PK - Perawat - Lab PK - Perawat - Dokter spesialis - Perawat

- Dokter - Lab PK - Perawat - Dokter spesialis - Perawat - Lab PK - Perawat

- Bisa jadi terdapat banyak perulangan maupun penyerahan pekerjaan bolak-balik beberapa kali pada bagian/pihak Perawat dan Lab PK.

\section{B. Analisis Penyerahan Pekerjaan}

Analisis kedua yang dilakukan adalah analisis mengenai pola penyerahan pekerjaan antar aktor. Analisis pola penyerahan pekerjaan dilakukan menggunakan hasil pengolahan pada ProM 5.2 (social network) serta menggunakan hasil pemodelan Petri net pada lampiran A untuk membantu analisa dari hasil ProM 5.2 yang menggunakan faktor causality. Event log yang digunakan terdiri atas 51 case, 40 aktor dan 119 jenis aktifitas. Berikut adalah hasil dari ProM 5.2 yaitu model social network. Model ini dibagi menjadi dua jenis yaitu yang memperhatikan causality (gambar 5) dan yang tidak memperhatikan causality (gambar 6). Kedua model menggunakan threshold yang sama yaitu 0,0085 untuk memudahkan analisa dengan menyingkirkan aktor yang memiliki nilai/bobot penyerahan pekerjaan di bawah 0,0085 . 

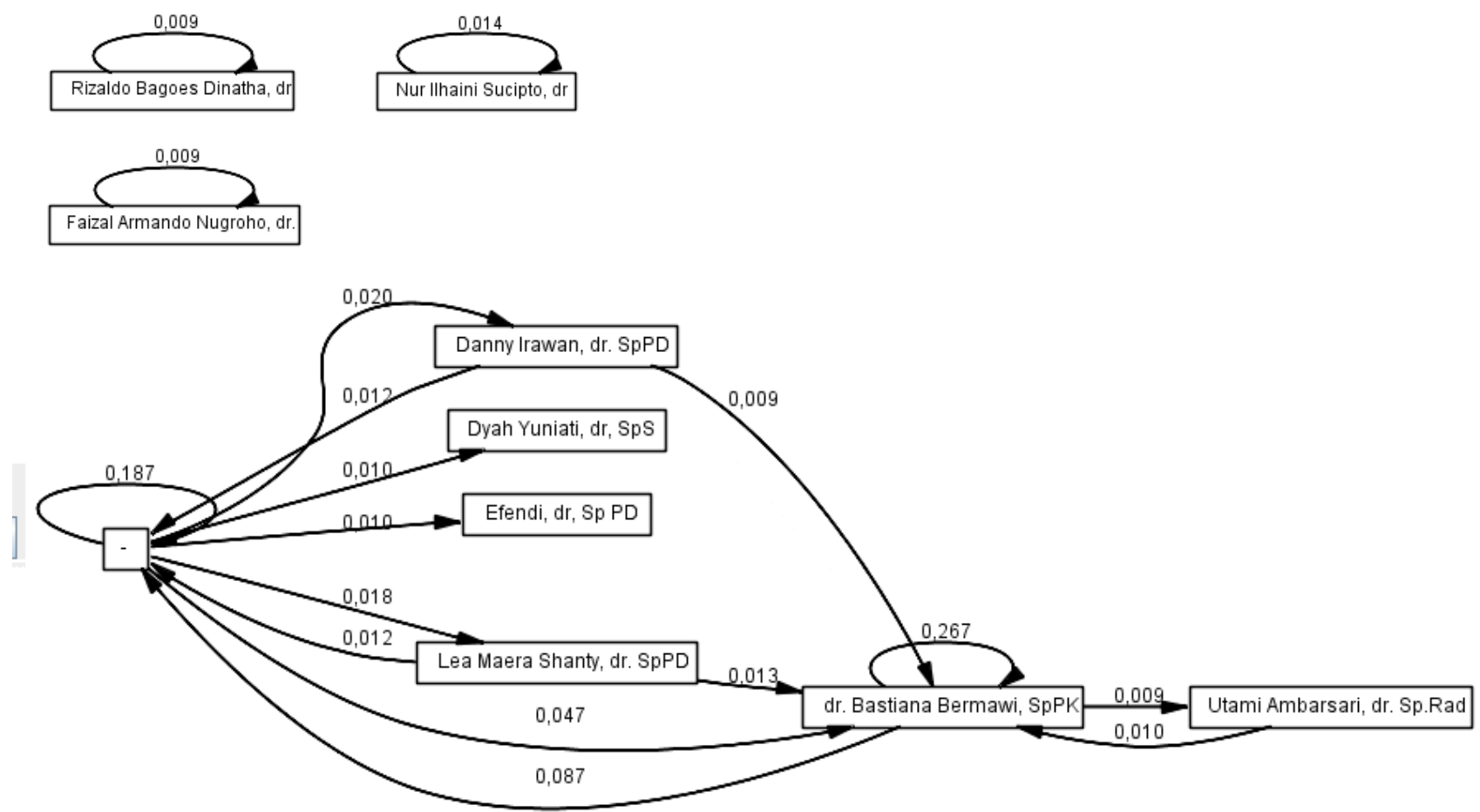

Gambar 6 Diagram social network tanpa causality

Setelah didapat kedua model, maka selanjutnya dilakukan analisis perbandingan antara kedua model.

\section{C.Analisis Perbandingan Model}

Analisis perbandingan metric dilakukan dengan membandingkan pola dan kinerja penyerahan pekerjaan antara diagram yang memperhatikan causality dan yang tidak pada social network yang telah dihasilkan.

Perbandingan antar diagram dilakukan untuk membandingkan apa yang tercatat pada event log dengan yang terjadi di dunia nyata (faktor causality). Dengan metric yang berbeda pada threshold yang sama, didapat perbedaan maupun persamaan sebagai berikut:

- Rizaldo, Faizal dan Nur Ilhaini menjadi aktor yang terpisah dari diagram utama pada kedua diagram. Hal ini berarti ketiganya lebih sering menyelesaikan pekerjaannya sendiri.

- Rizaldo, Faizal dan Nur Ilhaini memiliki nilai yang berbeda di antara dua diagram, dan memiliki nilai yang sedikit lebih rendah pada diagram yang tidak mempertimbangkan causality.

o Rizaldo memiliki nilai 0,010 pada diagram yang mempertimbangkan causality dan memiliki nilai 0,009 pada diagram yang tidak mempertimbangkan causality.

o Faizal memiliki nilai 0,010 pada diagram yang mempertimbangkan causality dan memiliki nilai 0,009 pada diagram yang tidak mempertimbangkan causality.

o Nur Ilhaini memiliki nilai 0,016 pada diagram yang mempertimbangkan causality dan memiliki nilai 0,014 pada diagram yang tidak mempertimbangkan causality.

- Terdapat perbedaan utama yaitu perbedaan bentuk diagram utama yang menghubungkan beberapa aktor sekaligus. Pada diagram yang mempertimbangkan Causality, terdapat 3 aktor yaitu perawat, Bastiana dan Utami. Sedangkan pada diagram yang tidak mempertimbangkan Causality, terdapat
7 aktor yaitu perawat, Danny, Dyah, Efendi, Lea, Bastiana dan Utami.

- Perawat, Bastiana dan Utami ketiganya ada pada kedua diagram namun dengan perbedaan hubung an (panah) dan bobot.

o Pada diagram pertama, perawat memiliki hubungan penyerahan pekerjaan kepada Bastiana sebesar 0,039 dan sebesar 0,093 untuk arah sebaliknya. Pada diagram kedua, perawat memiliki hubungan penyerahan pekerjaan kepada Bastiana sebesar 0,047 dan sebesar 0,087 untuk arah sebaliknya.

o Pada diagram pertama, Bastiana memiliki hubungan penyerahan pekerjaan kepada Utami sebesar 0,016 dan sebesar 0,013 untuk arah sebaliknya. Pada diagram kedua, Bastiana memiliki hubungan penyerahan pekerjaan kepada Utami sebesar 0,009 dan sebesar 0,010 untuk arah sebaliknya.

o Pada diagram pertama, Utami memiliki hubungan penyerahan pekerjaan kepada perawat sebesar 0,015. Pada diagram kedua, perawat tidak memiliki memiliki hubungan penyerahan pekerjaan langsung kepada Utami.

- Pada diagram pertama, dapat dilihat perawat dan Bastiana menyelesaikan pekerjaannya sendiri dengan bobot masingmasing 0,185 dan 0,390. Pada diagram kedua, perawat dan Bastiana menyelesaikan pekerjaannya sendiri dengan bobot masing-masing 0,187 dan 0,267.

- Pada diagram kedua, perawat memiliki hubungan penyerahan pekerjaan kepada Danny sebesar 0,020 dan sebesar 0,012 untuk arah sebaliknya.

- Pada diagram kedua, perawat memiliki hubungan penyerahan pekerjaan kepada Dyah sebesar 0,010.

- Pada diagram kedua, perawat memiliki hubungan penyerahan pekerjaan kepada Efendi sebesar 0,010. 
- Pada diagram kedua, perawat memiliki hubungan penyerahan pekerjaan kepada Lea sebesar 0,018 dan sebesar 0,012 untuk arah sebaliknya.

- Pada diagram kedua, Danny memiliki hubungan penyerahan pekerjaan kepada Bastiana sebesar 0,009.

- Pada diagram kedua, Lea memiliki hubungan penyerahan pekerjaan kepada Bastiana sebesar 0,013.

\section{D.Analisis Jumlah Penyerahan Pekerjaan}

Analisis ini dilakukan untuk mengetahui aktor mana yang paling sering menyerahkan pekerjaan kepada aktor lain dan aktor mana yang paling jarang. Analisis dilakukan dengan melihat hasil perhitungan social network yang mempertimbangkan causality, baik diagramnya maupun tabel hasil perhitungannya. Untuk tabel rangking aktor dengan jumlah penyerahan pekerjaan terbanyak dan paling sedikit dapat dilihat pada tabel 2 dan 3 .

Tabel 2

Ranking teratas penyerahan pekerjaan

\begin{tabular}{clc}
\multicolumn{2}{c}{ Ranking teratas penyerahan pekerjaan } \\
\hline \hline \multirow{2}{*}{ No } & \multicolumn{1}{c}{ Nama } & $\begin{array}{c}\text { Jumlah aktor yang } \\
\text { diberi pekerjaan }\end{array}$ \\
\hline 1 & dr. Bastiana Bermawi, SpPK & 15 \\
2 & Perawat & 13 \\
3 & Utami Ambarsari, dr. Sp.Rad & 6 \\
\hline \hline
\end{tabular}

Tabel 3

Rangking terbawah penyerahan pekerjaan

\begin{tabular}{clc}
\hline No & \multicolumn{1}{c}{ Nama } & $\begin{array}{c}\text { Jumlah Aktor yang } \\
\text { diberi pekerjaan }\end{array}$ \\
\hline 1 & Wita Kartika, dr. Sp. PD & 0 \\
2 & Nur Aisah Wardani, dr. Sp P & 0 \\
3 & Mouli Edward, dr.SpOT & 0 \\
4 & Henry Wahyu S. drg, SpBM & 0 \\
5 & Artaria Tjempakasari, dr. Sp PD - KGH & 0 \\
6 & Aditya Bayu Sakti P, dr, SpB & 0 \\
\hline \hline
\end{tabular}

Dari kedua tabel di atas terdapat hal unik, yaitu adanya dokter penyakit dalam (Sp.PD) yang terdapat pada tabel rangking terbawah. Hal tersebut dapat dibilang unik karena adanya dokter penyakit dalam yang hampir tidak berkontribusi sama sekali dalam menangani pasien diabetes, yang mana merupakan salah satu penyakit dalam. Sedangkan yang paling banyak melakukan penyerahan pekerjaan adalah petugas Lab PK, perawat dan radiolog.

\section{KESIMPULAN}

\section{A. Kesimpulan}

Kesimpulan yang dapat diambil dari Tugas Akhir ini adalah sebagai berikut:

1. Dari Petri net dan diagram social network yang didapat, diperoleh informasi alur pelayanan pasien sebagai berikut:

a. Pasien selalu dilayani terlebih dahulu oleh Dokter.

b. Pasien melanjutkan perawatan pada Lab Patologi Klinik.

c. Pasien dirawat di ruangan masing-masing oleh perawat.

d. Pasien melakukan kunjungan ke dokter spesialis.

e. Pasien kembali ke kamar untuk dirawat. Dari sini, pasien dapat pulang, atau mengulangi ke poin $\mathrm{b}$ ataupun $\mathrm{c}$.
2. Dari analisa pola penyerahan pekerjaan aktor yang dibagi menurut pekerjaannya, dan dengan mempertimbangkan causality, melalui diagram social network dan Petri net yang dihasilkan didapat hasil sebagai berikut:

a. Dokter (umum) selalu mengawali semua aktifitas pada proses perawatan pasien diabetes.

b. Sebaliknya, perawat selalu mengakhiri semua aktifitas pada proses perawatan pasien diabetes.

3. Dari analisa siapa/bagian mana yang melakukan penyerahan pekerjaan paling banyak dan yang paling sedikit, didapat bahwa:

a. Terdapat tiga bagian yang paling sering menyerahkan pekerjaan, yaitu: Perawat, Lab PK, Lab Radiologi.

b. Terdapat beberapa dokter yang hampir tidak menyerahkan pekerjaan sama sekali yaitu Wita Kartika, dr. Sp. PD, Nur Aisah Wardani, dr. Sp P, Mouli Edward, dr.SpOT, Henry Wahyu S. drg, SpBM, Artaria Tjempakasari, dr. Sp PD KGH, Aditya Bayu Sakti P, dr, SpB.

\section{B. Saran}

Saran yang dapat dipertimbangkan untuk pengembangan tugas akhir ini yaitu:

1. Jumlah case, dalam hal ini jumlah pasien, perlu ditingkatkan supaya dapat mencakup lebih banyak aktor dan aktifitas yang ada.

2. Dari sekian banyak case yang digunakan, setidaknya ada beberapa yang memiliki alur yang sama persis supaya variannya tidak terlalu banyak.

\section{UCAPAN TERIMA KASIH}

Terima kasih kepada seluruh pihak yang mendukung penelitian ini, RSI Jemursari, Jurusan Sistem Informasi, Fakultas Teknologi Informasi, ITS, teman-teman serta keluarga yang selalu memberikan dukungan. Dan terutama kepada Allah SWT. atas segala rahmat dan hidayahnya.

\section{DAFTAR PUSTAKA}

[1] W. Meethaisong and W. Premchaiswadi, "Applying Social network Miner on Medical Event logs using Handover of work Metric", Bangkok, 2015.

[2] W. Meethaisong and W. Premchaiswadi, "Analysis of the Social network Miner (Working together) of Physicians", Bangkok, 2015.

[3] Van der Aalst, W., Weijters, T., \& Maruster, L. (2004). Workflow Mining : Discovering Process Models from Event logs. IEEE Transaction on Knowledge and Data Engineering, 1128-1142.

[4] W. van der Aalst. "Process Mining: Discovery, Conformance and Enhancement of Business Processes". Springer-Verlag, Berlin, 2011.

[5] R. Cross. "Knowing what we know: Supporting knowledge creation and sharing in social networks". Organizational Dynamics, 30, 100-120, 2001. 